\title{
Thermoregulatory response in hair sheep and shorn wool sheep
}

\author{
Cristiane Gonçalves Titto ${ }^{\mathrm{a}, *}$, Cecília José Veríssimo ${ }^{\mathrm{b}}$, Alfredo Manuel Franco Pereira ${ }^{\mathrm{c}}$, \\ Ana de Mira Geraldo ${ }^{c}$, Luciana Morita Katiki ${ }^{b}$, Evaldo Antonio Lencioni Titto ${ }^{\text {a }}$ \\ a Laboratório de Biometeorologia e Etologia, Faculdade de Zootecnia e Engenharia de Alimentos, Universidade de São Paulo, Av. Duque de Caxias Norte 225, \\ Pirassununga, SP 13635-900, Brazil \\ ${ }^{\mathrm{b}}$ Instituto de Zootecnia (APTA/SAA), R. Heitor Penteado, 56, Centro, Nova Odessa, SP, 13460-000, Brazil \\ c Instituto de Ciências Agrárias e Ambientais Mediterrânicas (ICAAM), Universidade de Évora, Núcleo da Mitra, Ap. 94, Évora, 7002-554, Portugal
}

\section{A R T I C L E I N F O}

\section{Article history:}

Received 9 June 2016

Received in revised form 5 October 2016

Accepted 9 October 2016

Available online 11 October 2016

\section{Keywords:}

Adaptability

Heat challenge

Thermotolerance index

\begin{abstract}
A B S T R A C T
This study's main goal was to evaluate the thermoregulatory responses velocity through the variation of rectal temperature (RT), related to the thermolytic pathways, respiratory rate (RR) and sweating rate (SR) among different sheep breeds. Ninety female sheep, eighteen of each breed: Santa Ines and Morada Nova (Brazilian hair breeds), Texel, Suffolk and Ile de France (wool breeds) were challenged during three non-consecutive summer days $\left(22^{\circ} 42^{\prime} \mathrm{S}, 47^{\circ} 18^{\prime} \mathrm{W}\right.$, and $570 \mathrm{~m}$ of altitude, maximum air temperature of $33.5^{\circ} \mathrm{C}$, average relative humidity of $52 \pm 6.9 \%$ ). The physiological variables were registered at $0800 \mathrm{~h}$ (T1), $1300 \mathrm{~h}$ (T2: after $2 \mathrm{~h}$ of shade rest), $1400 \mathrm{~h}$ (T3) (after one hour of sun exposure) and in the shade at $1415 \mathrm{~h}$ (T4), $1430 \mathrm{~h}$ (T5), $1445 \mathrm{~h}$ (T6) and $1500 \mathrm{~h}$ (T7) and a thermotolerance index (TCI) was calculated as (10-(T7 to T4)-T1). The statistical analysis was performed by a mathematical model including the fixed effects of breeds and time frames, and the interaction between these effects, besides random effects such as animal and day. The Santa Ines breed presented the lowest RT after sun exposure $\left(39.3 \pm 0.12^{\circ} \mathrm{C}\right.$; $\mathrm{P}<0.05$ ) and it was the only one to recover morning RT $60 \mathrm{~min}$ after heat stress ( 38.7 and 38.9 for $1300 \mathrm{~h}$ and $1500 \mathrm{~h} ; \mathrm{P}>0.05)$. Hair breeds presented RR lower $(\mathrm{P}<0.05)$ than wool breeds. Although thick wool or hair thickness differs among and within hair and wool breeds $(\mathrm{P}<0.05)$, SR did not differ among breeds and time $\left(227.7 \pm 16.44 \mathrm{~g} \mathrm{~m}^{-2} \mathrm{~h}^{-1} ; \mathrm{P}>0.05\right)$. The thermotolerance index did not differ among breeds, but it showed similar response $(\mathrm{P}>0.05) 45 \mathrm{~min}$ or $1 \mathrm{~h}$ of shade after sun exposure. One week post shearing is not enough to wool breeds present to show thermotolerance similar to hair breeds.
\end{abstract}

(c) 2016 Published by Elsevier B.V.

\section{Introduction}

Hot environment impairs production, reproduction and welfare (Finocchiaro et al., 2005; Llonch et al., 2015; Marai et al., 2007; Silanikove, 2000). Regarding livestock systems, it will be strategic to optimize the productivity of crops and forage and to improve the ability of animals to cope with environmental stress by management and selection (Nardone et al., 2010).

Genetic selection program carried out in optimally controlled conditions clearly improved production traits. However, it may enhance the animal's susceptibility to high ambient temperature due to the strong relationship between production level and metabolic heat production (Mirkena et al., 2010).

Heat loss capacity varies with the species, among breeds and within the same breed (Renaudeau et al., 2012). Sheep appear to

\footnotetext{
* Corresponding author.

E-mail address: crisgtitto@usp.br (C.G. Titto).
}

be less susceptible to heat stress than other domesticated ruminant species (Shkolnik and Choshniak, 2006). Nonetheless, it has a lack of information comparing the effects of heat stress on hair and shorn wool sheep available in the literature (Renaudeau et al., 2012). Wool acts as a protective barrier and difficult evaporation of water from the body, thus reducing heat loss trough sweating (Wojtas et al., 2014). Nevertheless, in shorn animals or hair sheep breeds, sweating may become much more important in the total heat loss (Marai et al., 2007).

Studies to know the physiological differences between hair sheep and wool breeds used in a tropical environment are a great step to help farmers who wish to sell breeders to hot regions and direct the choice of animals more adequate to hot weather.

The aim of this study was to determine the variations in rectal temperatures, respiratory rate and sweating rate on hair (Santa Ines and Morada Nova) and shorn wool sheep breeds (Ile de France, Suffolk e Texel), during a heat test to evaluate the thermoregulatory responses and the degree of thermotolerance. 


\section{Material and methods}

The experiment was conducted at the sheep unit of the Instituto de Zootecnia in Nova Odessa, SP, Brazil $\left(22^{\circ} 42^{\prime} \mathrm{S}, 47^{\circ} 18^{\prime} \mathrm{W}\right.$, and $570 \mathrm{~m}$ of altitude). The region is known for being dry temperate during winter and hot and humid in the summer with average temperatures of $22^{\circ} \mathrm{C}$, ranging from $13^{\circ} \mathrm{C}$ to $32^{\circ} \mathrm{C}$. Data were collected at the handling center of the sheep unit which has concrete floored pens, open area, individual pens, and containment area and squeeze shut in a covered area with ceramic shingles. All procedures were approved by the Research Ethics Committee of Faculdade de Zootecnia e Engenharia de Alimentos of Universidade de São Paulo and its protocol number is 13.1.456.74.2.

During the experimental period (0800-1500 h), the ambient air temperatures and relative humidity were recorded with a data logger (LogBox-RHT, Novus, Campinas, SP, Brazil). It was also registered black globe temperatures in the sun and in the shade were recorded with black globe thermometers held at $0,5 \mathrm{~m}$ above the surface. The black globe humidity indexes in the sun and in the shade (BGHIsun and BGHIsh) were calculated according to Buffington et al. (1981).

Morphological and physiological data were collected on 90 adult female non-lactating and non-pregnant sheep from five different breeds (18 animals per breed), including hair breeds and wool breeds. Santa Ines hair sheep (three groups with white, brown, or black coat, all with dark skin; $53 \pm 1.6 \mathrm{~kg}$ ), Morada Nova hair sheep (red coat, dark skin; $31.4 \pm 1.3 \mathrm{~kg}$ ), Ile de France (white wool, white hair, white skin; $57 \pm 2.1 \mathrm{~kg}$ ), Suffolk (white wool, black hair, dark skin; $59 \pm 2.3 \mathrm{~kg}$ ) and Texel (white wool, white hair, dark skin; $48 \pm 1.8 \mathrm{~kg}$ ) were selected with ages ranging from 1.5 to 4 years, with similar body condition score (3-3.5). The animals were kept on Panicum maximum cv. Aruana pasture with natural and artificial shaded areas, mineral mixture and water through near the handling center, where animals were evaluated. The wool breeds were shorn with average fleeces ( $4.96 \pm 0.97 \mathrm{~mm}$ in length) one week before the experiment allowing the thickness to be similar to hair breeds.

The procedure took place during 18 days on summer of December 2006 on hot and cloudless days with low airspeed observed at morning and at least $45^{\circ} \mathrm{C}$ in black globe thermometer at $1300 \mathrm{~h}$. To ensure that all animals were evaluated in the $15-\mathrm{min}$ break, each day a group of 15 sheep ( 3 of each breed randomly chosen) were analyzed and the test was repeated three times in non-consecutive days for each group. The animals were taken to the handling center in the morning, around $0730 \mathrm{~h}$ and rested in the shade. At $0800 \mathrm{~h}$ the first rectal temperature (RT1) and respiratory rate (RR1) were taken and registered. At $1100 \mathrm{~h}$, the same animals returned to the handling center where they rested for $2 \mathrm{~h}$ under the shade; RT2 and RR2 were recorded at $1300 \mathrm{~h}$. The next procedure was to take these animals to a concrete floor pen, with no shaded area where they were completely exposed to the sun, for one hour (1300-1400 h). At $1400 \mathrm{~h}$ the animals were moved to the shade area and the registration of RT3 and RR3 was made and repeated every 15 min until one hour of shade was completed (RT4, RT5, RT6, RT7, RR4, RR5, RR6, and RR7). From 1100 to 1500 h the animals were deprived of food and water. The heat challenge was adapted from Titto et al. (2011), which is usually used for cattle. The Thermotolerance Index (TCI) was calculated using the rectal temperatures by the following formula: 10-(RTa - RT2). RTa was registered every $15 \mathrm{~min}$ interval after sun exposure: 1415 (RT4), 1430 (RT5), 1445 (RT6) and $1500 \mathrm{~h}$ (RT7). Lower TCIs characterizes the less heat-tolerant animals.

Firstly, RR was measured by a trained person through visual observation of rib movement for $60 \mathrm{~s}$ at $1 \mathrm{~m}$ distance and these data were expressed as movements per minute (mov min $\left.{ }^{-1}\right)$. Then, a second operator collected RT with a clinical thermometer
(Instrutherm, Sao Paulo, SP, Brazil) inserted into the rectum with a minimal animal disturbance.

Sweating rates (SR) were measured at $0800 \mathrm{~h}$ and $1500 \mathrm{~h}$ by the Schleger and Turner (1965) method. It is based on the utilization of three filter paper discs impregnated with cobalt chloride in an adhesive tape to fix the filter paper discs onto the animal's skin on the shoulder. The time taken for the cobalt chloride colour change from blue to pink allows measurement of the sweating rate. As faster the colour change the greater the SR. All measurements were performed by the same operator using a chronometer to avoid subjectivity. The maximum test time was $5 \mathrm{~min}$, after that the measure was declined. An area on the shoulder was shaved to allow the tape to be fixed. SR was calculated and is displayed in $\mathrm{g} \mathrm{m}^{-2} \mathrm{~h}^{-1}$ using the formula: $S R=(22 \times 3600) /(2.06 \times t)$, where $t$ is the time to change colour in seconds.

The model for RT, RR, SR and TCI included breed, times of samples as a repeated measurement and the interactions breed $\times$ times as main effects, and random effects on animals and day. Means were compared by Tukey-Kramer test. Significance was set at $P \leq 0.05$ and all values were presented as the mean $(\mu)$ and one standard error of the mean (SEM). Data were tested for normality, homoscedasticity and sphericity by Kolmogorov-Smirnov, Levene and Mauchly tests, respectively, and the data of the 3 days were compared to assume they are similar $(P>0.05$; SAS Institute, Inc. 2013, Cary, NC, USA).

\section{Results}

Concerning the meteorological data (Table 1), the warmest periods of the day were at 1400 and $1415 \mathrm{~h}$. The highest values of BGT at the sun were at $1400\left(48.2^{\circ} \mathrm{C}\right)$ and in the shade were at 1415 $\left(32.0^{\circ} \mathrm{C}\right)$ consequently, the highest BGHI occurred in those periods (97.7 and 81.4, respectively).

The RT variations throughout the different periods of the day according to the animal's breed are present in Table 2 . There were differences among breed and time factors and interaction breedtime on RT $(\mathrm{P}<0.05)$. Within Santa Ines different coat colors no differences were found for RT and RR $(\mathrm{P}>0.05)$, so all group colors were considered just for the breed.

In the morning (at $0800 \mathrm{~h}$ ), the only breeds with major differences in relation to RT $(\mathrm{P}<0.05)$ were Santa Ines and Texel. At $1300 \mathrm{~h}$, the lowest mean for RT was from Santa Ines breed $\left(38.68 \pm 0.11^{\circ} \mathrm{C}\right)$ and it was different from the others breeds $(\mathrm{P}<0.05)$ except for Morada Nova breed $\left(38.8 \pm 0.13^{\circ} \mathrm{C} ; \mathrm{P}>0.05\right)$. On the other hand, the highest RT was found for Ile de France breed $\left(39.15 \pm 0.14^{\circ} \mathrm{C}\right)$. After one hour of sun exposure $(1400 \mathrm{~h})$, the average RT of Santa Ines was still the lowest $\left(39.15 \pm 0.14^{\circ} \mathrm{C}\right)$ and different $(\mathrm{P}<0.05)$ from all of the others breeds but the highest was from Suffolk sheep $\left(39.96 \pm 0.13^{\circ} \mathrm{C}\right)$. At 1415,1430 and $1445 \mathrm{~h}$ there were differences registered between the RT means of Santa Ines and Ile de France, Suffolk and Texel breeds $(\mathrm{P}<0.05)$, with Santa Ines showing the lowest values $\left(39.17 \pm 0.12^{\circ} \mathrm{C}, 39.02 \pm 0.11^{\circ} \mathrm{C}\right.$, $38.93 \pm 0.10^{\circ} \mathrm{C}$, respectively for each hour). However, the highest values at 1415 and $1430 \mathrm{~h}$ were for Suffolk sheep (39.67 \pm 0.11 and $39.51 \pm 0.11^{\circ} \mathrm{C}$ ), and at 1445 and $1500 \mathrm{~h}$ for Texel sheep $\left(39.43 \pm 0.11^{\circ} \mathrm{C}\right.$ and $\left.39.40 \pm 0.11^{\circ} \mathrm{C}\right)$. It was observed that only one hair breed (Santa Ines) could dissipate all heat stored after one hour in the sun preceded by $45 \mathrm{~min}$ in the shade. At this time, Santa Ines sheep presented a similar RT value to the period before sun exposure $(\mathrm{P}>0.05)$. On the other hand, none of the others breeds recovered the RT values $(\mathrm{P}<0.05)$.

As expected, the RT increased in all breeds after heat stress $(1400 \mathrm{~h})$ and varied $(\mathrm{P}<0.05)$ from the ones observed before the heat stress (at 0800 and $1300 \mathrm{~h}$ ). 
Table 1

Means and standard error of meteorological parameters on recording times of physiological measures during the experimental period.

\begin{tabular}{|c|c|c|c|c|c|c|}
\hline \multirow[t]{2}{*}{ Time } & \multicolumn{6}{|l|}{ Variables $^{\mathrm{a}}$} \\
\hline & AT & UR & BGTsun & BGTsh & BGHIsun & BGHIsh \\
\hline $0800 \mathrm{~h}$ & $26.4 \pm 1.39$ & $74 \pm 4.5$ & $36.7 \pm 2.94$ & $25.6 \pm 1.43$ & $86.6 \pm 2.87$ & $75.5 \pm 2.30$ \\
\hline $1300 \mathrm{~h}$ & $31.6 \pm 1.83$ & $51 \pm 7.1$ & $47.2 \pm 3.96$ & $30.6 \pm 1.86$ & $96.6 \pm 4.54$ & $80.0 \pm 2.12$ \\
\hline $1400 \mathrm{~h}$ & $32.7 \pm 1.92$ & $49 \pm 7.7$ & $48.2 \pm 5.19$ & $31.2 \pm 1.84$ & $97.7 \pm 5.60$ & $80.8 \pm 2.34$ \\
\hline $1415 \mathrm{~h}$ & $33.5 \pm 1.69$ & $46 \pm 7.9$ & $46.6 \pm 2.69$ & $32.0 \pm 1.41$ & $96.0 \pm 3.64$ & $81.4 \pm 2.24$ \\
\hline $1430 \mathrm{~h}$ & $32.9 \pm 1.91$ & $49 \pm 6.6$ & $45.3 \pm 4.75$ & $31.3 \pm 1.64$ & $94.9 \pm 5.00$ & $80.9 \pm 2.23$ \\
\hline $1445 \mathrm{~h}$ & $32.9 \pm 1.87$ & $48 \pm 6.5$ & $44.0 \pm 5.40$ & $31.3 \pm 1.66$ & $93.5 \pm 5.2$ & $80.8 \pm 1.92$ \\
\hline $1500 \mathrm{~h}$ & $32.8 \pm 1.89$ & $48 \pm 6.1$ & $44.9 \pm 5.26$ & $31.2 \pm 1.88$ & $94.3 \pm 5.5$ & $80.7 \pm 2.20$ \\
\hline
\end{tabular}

a AT: Air temperature $\left({ }^{\circ} \mathrm{C}\right)$, UR: Relative Humidity (\%), BGTsun: black globe temperature in the sun $\left({ }^{\circ} \mathrm{C}\right)$, BGTsh: black globe temperature under the shade $\left({ }^{\circ} \mathrm{C}\right)$, BGHIsun: black globe humidity index in the sun, BGHIsh: black globe humidity index under the shade.

Table 2

Means and standard error of rectal temperature of hair breeds and shorn wool breeds of sheep during a heat challenge.

\begin{tabular}{|c|c|c|c|c|c|}
\hline \multirow[t]{2}{*}{ Time } & \multirow[t]{2}{*}{ SI } & \multirow[t]{2}{*}{$\mathrm{MN}$} & \multicolumn{3}{|l|}{ Breeds } \\
\hline & & & IF & SU & $\mathrm{TE}$ \\
\hline $0800 \mathrm{~h}$ & $38.72 \pm 0.09^{\mathrm{Bc}}$ & $38.92 \pm 0.10^{\mathrm{ABC}}$ & $39.05 \pm 0.13^{\mathrm{ABC}}$ & $38.87 \pm 0.10^{\mathrm{Abc}}$ & $39.17 \pm 0.12^{\mathrm{Ac}}$ \\
\hline $1300 \mathrm{~h}$ & $38.68 \pm 0.11^{\mathrm{Bc}}$ & $38.81 \pm 0.13^{\mathrm{ABC}}$ & $39.15 \pm 0.14^{\mathrm{Ac}}$ & $39.08 \pm 0.11^{\mathrm{Ac}}$ & $39.12 \pm 0.13^{\mathrm{Ac}}$ \\
\hline $1400 \mathrm{~h}$ & $39.29 \pm 0.12^{\mathrm{Ba}}$ & $39.64 \pm 0.12^{\mathrm{Aa}}$ & $39.73 \pm 0.16^{\mathrm{Aa}}$ & $39.96 \pm 0.13^{\mathrm{Aa}}$ & $39.79 \pm 0.14^{\mathrm{Aa}}$ \\
\hline $1415 \mathrm{~h}$ & $39.17 \pm 0.12^{\mathrm{Bab}}$ & $39.33 \pm 0.14^{\mathrm{ABab}}$ & $39.69 \pm 0.14^{\text {Aab }}$ & $39.67 \pm 0.11^{\text {Aab }}$ & $39.59 \pm 0.11^{\text {Aab }}$ \\
\hline $1430 \mathrm{~h}$ & $39.02 \pm 0.11^{\text {Bab }}$ & $39.18 \pm 0.14^{\mathrm{ABab}}$ & $39.48 \pm 0.13^{\text {Aab }}$ & $39.51 \pm 0.11^{\text {Aab }}$ & $39.49 \pm 0.11^{\text {Aab }}$ \\
\hline $1445 \mathrm{~h}$ & $38.93 \pm 0.10^{\mathrm{Bbc}}$ & $39.14 \pm 0.12^{\mathrm{ABb}}$ & $39.42 \pm 0.13^{\mathrm{Ab}}$ & $39.39 \pm 0.11^{\mathrm{Ab}}$ & $39.43 \pm 0.11^{\mathrm{Ab}}$ \\
\hline $1500 \mathrm{~h}$ & $38.95 \pm 0.10^{\mathrm{Bbc}}$ & $39.14 \pm 0.12^{\mathrm{ABb}}$ & $39.34 \pm 0.13^{\mathrm{Ab}}$ & $39.34 \pm 0.11^{\mathrm{Ab}}$ & $39.40 \pm 0.11^{\mathrm{Ab}}$ \\
\hline
\end{tabular}

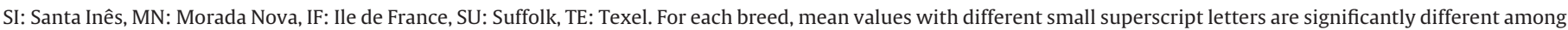
hours $(\mathrm{P}<0.05)$. For each hour, mean values with different capital superscript letters are different among breeds $(\mathrm{P}<0.05)$.

Table 3

Means and standard error of respiratory rate of hair breeds and shorn wool breeds of sheep during a heat challenge.

\begin{tabular}{|c|c|c|c|c|c|}
\hline \multirow[t]{2}{*}{ Time } & \multirow[t]{2}{*}{ SI } & \multirow[t]{2}{*}{ MN } & \multicolumn{3}{|l|}{ Breeds } \\
\hline & & & $\mathrm{IF}$ & SU & TE \\
\hline $0800 \mathrm{~h}$ & $31 \pm 4.5^{\mathrm{BC}}$ & $37 \pm 4.9^{\mathrm{Bd}}$ & $86 \pm 9.3^{\mathrm{Ac}}$ & $76 \pm 8.4^{\mathrm{Ac}}$ & $83 \pm 9.0^{\mathrm{Ad}}$ \\
\hline $1300 \mathrm{~h}$ & $32 \pm 4.6^{\mathrm{Bc}}$ & $33 \pm 4.7^{\mathrm{Bd}}$ & $83 \pm 9.0^{\mathrm{Ac}}$ & $81 \pm 8.8^{\mathrm{Ac}}$ & $91 \pm 9.7^{\mathrm{Ad}}$ \\
\hline $1400 \mathrm{~h}$ & $65 \pm 7.5^{\mathrm{Ca}}$ & $82 \pm 8.9^{\mathrm{Ba}}$ & $174 \pm 16.6^{\mathrm{Aa}}$ & $163 \pm 15.7^{\mathrm{Aa}}$ & $165 \pm 15.9^{\mathrm{Aa}}$ \\
\hline $1415 \mathrm{~h}$ & $42 \pm 6.2^{\mathrm{cb}}$ & $63 \pm 7.8^{\mathrm{Bb}}$ & $140 \pm 14.5^{\mathrm{Aab}}$ & $144 \pm 14.8^{\mathrm{Aa}}$ & $126 \pm 13.2^{\mathrm{Ab}}$ \\
\hline $1430 \mathrm{~h}$ & $39 \pm 5.2^{\mathrm{Bbc}}$ & $44 \pm 5.6^{\mathrm{Bc}}$ & $138 \pm 13.6^{\mathrm{Ab}}$ & $129 \pm 12.9^{\text {Aab }}$ & $119 \pm 12.1^{\mathrm{Ab}}$ \\
\hline $1445 \mathrm{~h}$ & $35 \pm 4.9^{\mathrm{Bc}}$ & $41 \pm 5.4^{\mathrm{Bcd}}$ & $125 \pm 12.5^{\mathrm{Ab}}$ & $121 \pm 12.2^{\mathrm{Ab}}$ & $116 \pm 11.8^{\mathrm{Abc}}$ \\
\hline $1500 \mathrm{~h}$ & $29 \pm 4.3^{\mathrm{BC}}$ & $37 \pm 4.9^{\mathrm{Bd}}$ & $112 \pm 11.4^{\mathrm{Ab}}$ & $106 \pm 10.9^{\mathrm{Ab}}$ & $113 \pm 10.0^{\mathrm{Ac}}$ \\
\hline
\end{tabular}

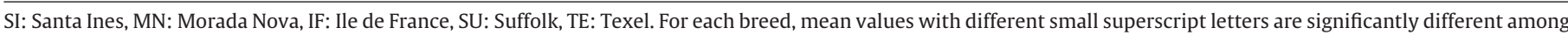
hours $(P<0.05)$. For each hour, mean values with different capital superscript letters are different among breeds $(P<0.05)$.

The RR was affected by breed and hours and interactions between them $(\mathrm{P}<0.05)$ (Table 3$)$. Hair breed Santa Ines and Morada Nova formed a group with values almost three times lower than the wool breeds $(\mathrm{P}<0.05)$.

In the first period $(0800 \mathrm{~h})$ the RR values of Santa Ines and Morada Nova breeds were different from the others breeds (Ile de France, Suffolk and Texel; $\mathrm{P}<0.05$ ) but not different from each other $(\mathrm{P}>0.05)$. The same was observed at $1300,1430,1445$ and $1500 \mathrm{~h}$. During the warmer periods ( 1400 and $1415 \mathrm{~h}$ ), Ile de France, Suffolk and Texel did not show differences for RR $(P>0.05)$ but they presented the high values $(\mathrm{P}<0.05)$.

After $30 \mathrm{~min}$ in the shade, Santa Ines had RR similar to the frequency before sun exposure $\left(32 \pm 4.6\right.$ and $39 \pm 5.2 \mathrm{mov} \mathrm{min}^{-1}$ respectively; $\mathrm{P}>0.05$ ), besides Morada Nova needed $45 \mathrm{~min}$ to reach similar basal value. Even tough, after one hour in the shade $(1500 \mathrm{~h})$ it was observed higher RR means for the hair breeds compared to the morning and before sun exposure $(\mathrm{P}<0.05$; Table 3$)$. RR reached $174 \mathrm{mov} \mathrm{min}^{-1}$ for Ile de France and even after $60 \mathrm{~min}$ under the shade all wool sheep did not reduce RR to the frequencies observed before heat stress $(\mathrm{P}<0.05)$.

Sweating rate did not differ between periods and breeds ( $P>0.05$; Table 4). Ile de France was the breed with the lowest value $\left(186.8 \mathrm{~g} \mathrm{~m}^{-2} \mathrm{~h}^{-1}\right)$ and Texel with the highest $\left(251.2 \mathrm{~g} \mathrm{~m}^{-2} \mathrm{~h}^{-1}\right)$. Hair thickness differs between breeds after shearing, and Morada
Table 4

Means and standard error of sweating rate $\left(\mathrm{g} \mathrm{m}^{-2} \mathrm{~h}^{-1}\right)$ and thick wool or hair thickness $(\mathrm{T})$ in hair breeds and shorn wool breeds of sheep.

\begin{tabular}{lll}
\hline Breed & Sweating rate & $\mathrm{T}(\mathrm{mm})$ \\
\hline Santa Ines & $230.2 \pm 41.1$ & $4.3 \pm 0.68^{\mathrm{a}}$ \\
Morada Nova & $231.7 \pm 51.6$ & $3.3 \pm 0.68^{\mathrm{c}}$ \\
Ile de France & $186.8 \pm 39.1$ & $4.7 \pm 1.12^{\mathrm{a}}$ \\
Suffolk & $239.6 \pm 37.7$ & $4.5 \pm 0.94^{\mathrm{a}}$ \\
Texel & $251.2 \pm 39.2$ & $6.0 \pm 1.43^{\mathrm{b}}$ \\
Mean & $277.9 \pm 16.44$ & - \\
\hline
\end{tabular}

For each parameter, mean values with different small superscript letters are significantly different among breeds $(\mathrm{P}<0.05)$.

Nova $(3.3 \mathrm{~mm})$ and Texel $(6.0 \mathrm{~mm})$, had differences among them and the others breeds $(\mathrm{P}<0.05)$.

Thermotolerance Index (TCI) did not differ between breeds, but there was an effect of hours $(\mathrm{P}<0.05$; Table 5$)$. TCI based on RT6 and RT7 were similar $(\mathrm{P}>0.05)$.

\section{Discussion}

The hypothesis for the present work was that wool breeds after shearing could present thermotolerance as heat dissipation similar to hair breeds. The results did not support this hypothesis. 
Table 5

Means and standard error of thermotolerance index (TCI) of sheep during a heat challenge.

\begin{tabular}{lllll}
\hline & RT4 & RT5 & RT6 & RT7 \\
\hline Mean & $9.45(0.048)^{\mathrm{a}}$ & $9.63(0.047)^{\mathrm{b}}$ & $9.70(0.048)^{\mathrm{c}}$ & $9.73(0.048)^{\mathrm{c}}$
\end{tabular}

$\mathrm{TCI}=10$-(RT2-Rta), where RTa = 1415 (RT4), 1430 (RT5), 1445 (RT6), $1500 \mathrm{~h}$ (RT7). Mean values with different small superscript letters are significantly different among hours $(\mathrm{P}<0.05)$.

BGHI over 78 indicates a potentially stressful environment for sheep (Hahn, 1985). In this study, the BGHI in the sun was always superior to 90 except in the first period, suggesting that heat exposure during the challenge can be considered a very stressful condition. As a consequence of the upper values for BGT, RT, RR and SR increased. Adaptations to environmental heat stress may involve metabolic heat production, evolving in maintenance and production processes, as well as heat loss from the body. The heat generated in the body is used in the maintenance of body temperature, and amounts more than that required are dissipated to the environment by evaporative and non-evaporative pathways (Finch, 1986; West, 2003).

The respiratory evaporation is a physiological mechanism used in intense responses for shorter periods of the day (Silva and Starling, 2003) and it is very important for thermoregulation in sheep (Brockway et al., 1965; Mcmanus et al., 2009; Silva et al., 2002). An increase in RT and RR in the afternoon, when the air temperature is higher, it is commonly observed (Mcmanus et al., 2009; Veríssimo et al., 2009), as well as an increase in summer (MacíasCruz et al., 2016a,b). Similar differences in rectal temperature (39.6 vs. $\left.40.1^{\circ} \mathrm{C} ; \mathrm{P}<0.05\right)$ and respiration rate $(63$ vs. 80 breaths/min; $\mathrm{P}$ $0<0.05)$ at elevated environmental chamber temperatures $\left(30^{\circ} \mathrm{C}\right)$ between hair (SC) and wool (Targhee) sheep were reported by Horton et al. (1991).

In the early morning, RR of wool breeds has higher values than those of hair breeds. This difference may be related to a higher metabolic rate of wool sheep together with a decreased ability to lose heat by sensible route due to the insulating wool effect (Goode et al., 1983; Horton et al., 1991; Ross et al., 1985). The responses of wool breeds are quite similar.

In sheep, be panting is the major evaporative heat loss mechanism and respiratory rate tends to follow closely the evaporation heat loss (Hales and Brown, 1974). The severity of heat stress due to RR was classified by Silanikove (2000), where $40-6$ mov min $^{-1}$ characterized low stress, $60-80 \mathrm{mov} \mathrm{min}^{-1}$ medium-high stress, $80-120 \mathrm{mov} \mathrm{min}^{-1}$ high stress, and above $200 \mathrm{mov} \mathrm{min}^{-1}$ the sheep would be in severe stress.

On the other hand, the sun exposure caused quite different reaction between hair and wool breeds about respiratory losses. The largest heat gain in wool breeds in this study was not always observed in other studies, in which animals remain in the sun and only RR increases with the little change in the RT (Wojtas et al., 2014). A probable cause for this occurrence in this study is the fact that animals are sheared. Under these conditions, the insulating effect and protector of wool on shorn sheep are attenuated and probably there was a higher transmissivity, yielding a greater amount of energy reaching the skin. The considerable heat gain sets off the greatest need for the use of evaporative heat loss pathways, including the thermal polypnea. Despite the lower insulating effect of slightly thick wool, this also presents features which reduce the thermoregulation by convection. Indeed, even with the thinner wool there is air stability on the inside of the fleece, which results in a smaller loss of heat by convection.

Although wool also makes thermoregulation more difficult (Alhidary et al., 2012; Gebremedhin et al., 1997), shearing significantly reduces core body temperature, water intake, and respiratory rate (Al-Ramamneh et al., 2011; Siqueira et al., 1993). When there a fewer hairs per surface area, the wind can penetrate the coat more easily removing trapped air thereby favoring thermal transfer (Castanheira et al., 2010). However, in the present study one week after shearing, wool breeds still presented thermotolerance similar to unshorn sheep (Alhidary et al., 2012; Al-Ramamneh et al., 2011).

Animals with dark coat have greater absorption of thermal radiation and they are more susceptible to heat stress than those with a lighter coat colour (Mcmanus et al., 2009). However, in the present study, different coat colour of Santa Ines group did not show better heat adaptation as observed by McManus et al. (2011). A different relation between absorbance and transmittance can explain this result. The lower transmittance allowed that radiant heat was absorbed only in the outer surface. Thus, this absorbed heat was quickly removed by convection with less interference in the epidermis. On the other hand, this can be explained by the pigmented hair and skin observed in this breed which protects the skin against ultraviolet radiation (Sjaastad et al., 2010).

One aspect that should be referred is that in Morada Nova breed RT additions after sun exposure is similar to those seen in wool breeds. The higher specific surface of Morada Nova breed assumes a greater vulnerability to solar radiation (West, 2003). Despite the fact that the increases in RT are quite similar to wool breeds, the RR values are significantly lower than observed in Santa Ines. This divergence of results could suggest a greater participation of sweating in the thermoregulation. However, notwithstanding the sweating rate values are not high; they are similar to the Santa Ines breed. In this result, higher efficiency of water metabolism appears to be involved (Pereira et al., 2014). Another study with Morada Nova breed indicated a good ability to cope with the climatic changes of the Brazilian semiarid region as they presented low RT and $\mathrm{RR}\left(38.59 \pm 0.58^{\circ} \mathrm{C}\right.$ and $\left.42.26 \pm 8.96 \mathrm{mov} \mathrm{min}^{-1}\right)$ during hot days (Costa et al., 2015).

After sun exposure, the increased RT and RR of Santa Ines were significantly lower than the other breeds. This occurrence allows us to suppose that either the transmissivity is small (even considering the different coat colors) or sweating plays crucial role in thermoregulation, despite the fact that no significant differences were found. The sweating rates, remarkably high, can be considered as a thermoregulatory response aiming the stability of body temperature.

On the other hand, mainly in wool breeds RR exhibits a remarkable importance in thermoregulation. Only hair breeds managed to fully recover RR displayed at $1300 \mathrm{~h}$. The other breeds kept an important physiological effort to dissipate the heat stored during the presence under the sun. Sweating in wool sheep is much less important than respiratory evaporation because of the presence of a wool coat. However, besides sweating, sheep can also dissipate heat from the surface of the body as a result of water diffusion through the skin as insensible perspiration (Marai et al., 2007). In contrast, when compared by TCI, all breeds in this study were capable to lose heat after one hour in the shade after going through stress. Maybe the index cannot describe the thermoregulatory responses because of the low variability in data.

When comparing hair breeds, it should be noted that the Santa Ines showed a well-marked decrease in RT and a faster recovery of RR. This is an unusual result since the Morada Nova is a lightweight breed that has a high relative surface and it presents a greater ability to lose heat through the thermal polypnea. Actually, what happened is that the Morada Nova showed higher RR during a longer period but a slower RT recovery when compared to Santa Ines. Accordingly, it is reasonable to assume a greater participation of sweating in the Santa Ines thermoregulation, even with similar average values. 


\section{Conclusion}

Thermoregulatory responses between hair and wool sheep breeds can differ widely even if wool sheep are shorn. One week post shearing is not enough to wool breeds present thermotolerance similar to hair breeds, even these results indicating a higher participation of the sweating rate in thermal balance.

\section{References}

Al-Ramamneh, D., Gerken, D.M., Riek, A., 2011. Effect of shearing on water turnover and thermobiological variables in German blackhead mutton sheep. J. Anim. Sci. 89, 4294-4304.

Alhidary, I.A., Shini, S., Al Jassim, R.A.M., Gaughan, J.B.J., 2012. Physiological responses of Australian merino wethers exposed to high heat load. J. Anim. Sci. 90, 212-220.

Brockway, J.M., Mcdonald, J.D., Pullar, J.D., 1965. Evaporative heat-loss mechanisms in sheep. J. Physiol. 179, 554-568.

Buffington, D.E., Collazo-Arocho, A., Canton, G.H., Pitt, D., Thatcher, W.W., Collier, R.J., 1981. Black globe-humidity index (BGHI) as comfort equation for dairy cows. Trans. ASAE 24 (3), 711-0714.

Castanheira, M., Paiva, S.R., Louvandini, H., Landim, A., Fiorvanti, M.C.S., Dallago, B.S., Correa, P.S., McManus, C., 2010. Use of heat tolerance traits in discriminating between groups of sheep in central Brazil. Trop. Anim. Health Prod. 42 (8), 1821-1828.

Costa, W.P., Façanha, D.A.E., Leite, J.H.G.M., Silva, R.C.B., Souza, C.H., Chaves, D.F., Vasconcelos, A.M., Soto-Blanco, B., Vale, A.M., Pimenta Filho, E.C., 2015. Thermoregulatory responses and blood parameters of locally adapted ewes under natural weather conditions of Brazilian semiarid region. Cienc. Agrar. 36 (6), 4589-4600.

Finch, V.A., 1986. Body temperature in beef cattle: its control and relevance to production in the tropics. J. Anim. Sci. 62 (2), 531-542, http://dx.doi.org/10. 2134/jas1986.622531x.

Finocchiaro, R., Van Kaam, J.B.C.H.M., Portolano, B., Misztal, I., 2005. Effect of heat stress on production of Mediterranean dairy sheep. J. Dairy Sci. 88 (5), 1855-1864.

Gebremedhin, K.G., Ni, H., Hillman, P.E., 1997. Modeling temperature profile and heat flux through irradiated fur layer. Trans. ASAE 40 (5), 1441-1447.

Goode, L., Yazwinski, T.A., Moncol, D.J., Linnerud, A.C., Morgan, G.W., Tugman, D.F. 1983. Research with Barbados blackbelly sheep in north carolina. In: Fitzhugh, H.A., Bradford, G.E. (Eds.), Hair Sheep of Western Africa and the Americas: A Genetic Resource for the Tropics. Westview Press, Boulder, p. 257.

Hahn, G.L., 1985. Management and housing of farm animals in hot environments. In: Yousef, M.K. (Ed.), Stress Physiology in Livestock. Ungulates, vol. 2. CRC Press Inc., Boca Raton, pp. 151-174.

Hales, J.R.S., Brown, G.D., 1974. Net energetic and thermoregulatory efficiency during panting in the sheep. Comp. Biochem. Phys. A 49 (3), 413-422.

Horton, G.M.J., Emanuele, S.M., Solomon, M.B., Burguer, C.C., Mcclure, K.E., 1991. Physiological responses of hair and wool sheep to changes in ambient temperature and feed allowance. In: Wildeus, S. (Ed.), Proceedings of Hair Sheep Research Symposium. Univ. Virgin Islands St. Croix, p. 331.

Llonch, P., King, E.M., Clarke, K.A., Downes, J.M., Green, L.E., 2015. A systematic review of animal based indicators of sheep welfare on farm, at market and during transport, and qualitative appraisal of their validity and feasibility for use in UK abattoirs. Vet. J. 206 (3), 289-297.

Macías-Cruz, U., López-Baca, M.A., Vicente, R., Mejía, A., Alvarez, F.D., Correa-Calderón, A., Meza-Herrera, C.A., Mellado, M., Guerra-Liera, J.E., Avendaño-Reyes, L., 2016a. Effects of seasonal ambient heat stress (spring vs. summer) on physiological and metabolic variables in hair sheep located in an arid region. Int. J Biometeorol. 60 (8), 1279-1286.
Macías-Cruz, U., Gastélum, M.A., Álvarez, F.D., Correa, A., Díaz, R., Meza-Herrera, C.A., Mellado, M., Avendaño-Reyes, L., 2016b. Effects of summer heat stress on physiological variables, ovulation and progesterone secretion in Pelibuey ewes under natural outdoor conditions in an arid region. Anim. Sci J. 87 (3), 354-360.

Marai, I.F.M., El-Darawany, A.A., Fadiel, A., Abdel-Hafez, M.A.M., 2007. Physiological traits as affected by heat stress in sheep-a review. Small Rumin. Res. 71, 1-12, http://dx.doi.org/10.1016/j.smallrumres.2006.10.003.

McManus, C., Louvandini, H., Gugel, R., Sasaki, L.C.B., Bianchini, E., Bernal, F.E.M., Paiva, S.R., Paim, T.P., 2011. Skin and coat traits in Sheep in Brazil and their relation with heat tolerance. Trop. Anim. Health Prod. 43, 121-126.

Mcmanus, C., Paludo, G.R., Louvandini, H., Gugel, R., Sasaki, L.C., Paiva, S.R., 2009. Heat tolerance in Brazilian sheep: physiological and blood parameters. Trop. Anim. Health Prod. 41, 95-101.

Mirkena, T., Duguma, G., Haile, A., Tibbo, M., Okeyo, A.M., Wurzinger, M., Sölkner, J. 2010. Genetics of adaptation in domestic farm animals: a review. Livest. Sci. 132, 1-12, http://dx.doi.org/10.1016/j.livsci.2010.05.003.

Nardone, A., Ronchi, B., Lacetera, N., Ranieri, M.S., Bernabucci, U., 2010. Effects of climate changes on animal production and sustainability of livestock systems. Livest Sci. 130, 57-69.

Pereira, A.M.F., Titto, E.A.L., Infante, P., Titto, C.G., Geraldo, A.C.A.P.M., Leme, T.M., Baccari Jr, F., Almeida, J.A., 2014. Evaporative heat loss in Bos taurus: do different cattle breeds cope with heat stress in the same way? J. Therm. Biol. $45,87-95$

Renaudeau, D., Collin, A., Yahav, S., De Basilio, V., Gourdine, J.L., Collier, R.J., 2012. Adaptation to hot climate and strategies to alleviate heat stress in livestock production. Animal 6 (5), 707-728.

Ross, T.T., Goode, D., Linnerud, A.C., 1985. Effects of high ambient temperature on respiration rate, rectal temperature, fetal development and thyroid gland activity in tropical and temperate breeds of sheep. Theriogenolology 24 (2) 259-269.

Schleger, A.V., Turner, H.G., 1965. Sweating rates of cattle in the field and their reaction to diurnal and seasonal changes. Aust. J. Agric. Res. 16 (9), 2-106.

Shkolnik, A., Choshniak, I., 2006. Adaptation to Life in the Desert: The special physiology and history of the black bedouin boat, T. Shkolnik (ed.): pp 12-25, Koenigstein, Germany.

Silanikove, N., 2000. Effects of heat stress on the welfare of extensively managed domestic ruminants. Livest. Prod. Sci. 67, 1-18.

Silva, R.G., Starling, J.M.C., 2003. Cutaneous and respiratory evaporation rates of sheep in hot environments. Rev. Bras. Zootec. 32 (6), 1956-1961.

Silva, R.G., Lascala Jr., N., Lima Filho, A.E., Catharin, M.C., 2002. Respiratory heat loss in the sheep: a comprehensive model. Int. J. Biometeorol. 46, 136-140.

Siqueira, E.R., Fernandes, S., María, G.A., 1993. Efecto de la lana y del sol sobre algunos parámetros fisiológicos en ovejas de razas Merino Australiano, Corriedale, Romney Marsh e Ile de France, ITEA, 89A(2), 124-131.

Sjaastad, O.V., Hove, K., Sand, O., 2010. Physiology of Domestic Animals, 2nd ed. Scandinavian Veterinary Press, Oslo.

Titto, C.G., Titto, E.A.L., Titto, R.M., Mourão, G.B., 2011. Heat tolerance and the effects of shade on the behavior of Simmental bulls on pasture. Anim. Sci. J. 82, 591-600.

Veríssimo, C.J., Titto, C.G., Katiki, L.M., Bueno, M.S., Cunha, E.A.D., Mourão, G.B., Otsuk, I.P., Pereira, A.M.F., Nogueira Filho, J.C.M., Titto, E.A.L., 2009. Heat tolerance of Santa Ines ewes with light and dark colored pelage. Rev. Bras. Saúde Prod. An. 10 (1), 159-167.

West, J.W., 2003. Effects of heat-stress on production in dairy cattle. J. Dairy Sci. 86, 2131-2144

Wojtas, K., Cwynar, P., Kołacz, R., 2014. Effect of thermal stress on physiological and blood parameters in merino sheep. Bull. Vet. Inst. Pulawy. 58, 283-288. 